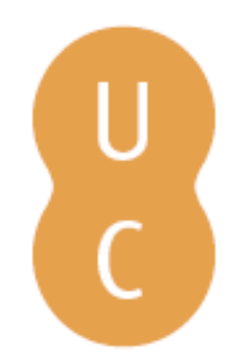

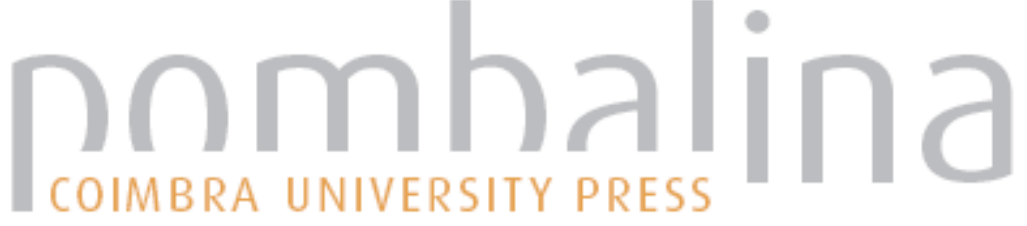

\section{Utopias distópicas na tragédia}
Autor(es):
Marques, Susana Hora
Publicado por: Imprensa da Universidade de Coimbra
URL persistente:
URI:http://hdl.handle.net/10316.2/32047
DOI:
DOI:http://dx.doi.org/10.14195/978-989-26-0499-2_4

Accessed : $\quad$ 26-Apr-2023 10:16:31

A navegação consulta e descarregamento dos títulos inseridos nas Bibliotecas Digitais UC Digitalis, UC Pombalina e UC Impactum, pressupõem a aceitação plena e sem reservas dos Termos e Condições de Uso destas Bibliotecas Digitais, disponíveis em https://digitalis.uc.pt/pt-pt/termos.

Conforme exposto nos referidos Termos e Condições de Uso, o descarregamento de títulos de acesso restrito requer uma licença válida de autorização devendo o utilizador aceder ao(s) documento(s) a partir de um endereço de IP da instituição detentora da supramencionada licença.

Ao utilizador é apenas permitido o descarregamento para uso pessoal, pelo que o emprego do(s) título(s) descarregado(s) para outro fim, designadamente comercial, carece de autorização do respetivo autor ou editor da obra.

Na medida em que todas as obras da UC Digitalis se encontram protegidas pelo Código do Direito de Autor e Direitos Conexos e demais legislação aplicável, toda a cópia, parcial ou total, deste documento, nos casos em que é legalmente admitida, deverá conter ou fazer-se acompanhar por este aviso. 
Maria de Fátima Silva

Coordenação

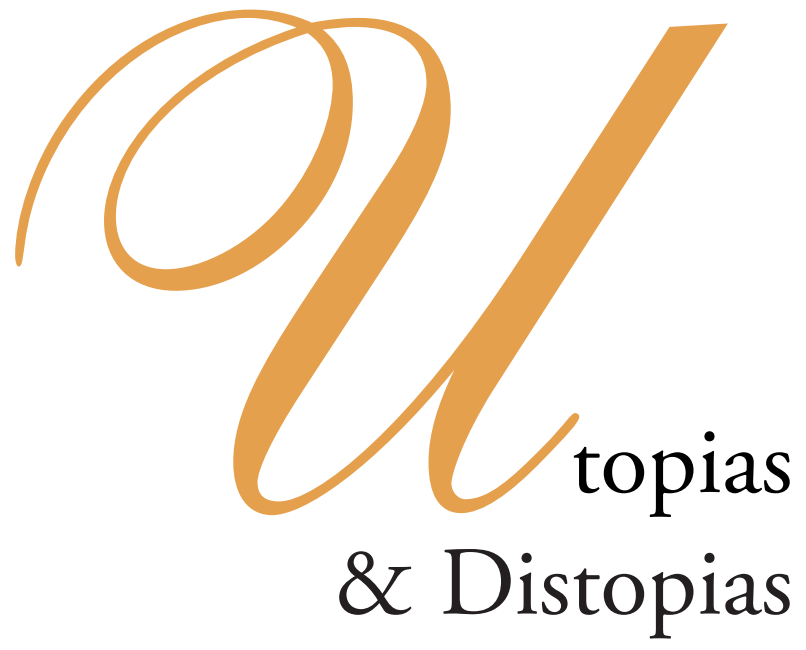




\section{COORDENAÇÃO EDITORIAL \\ Imprensa da Universidade de Coimbra \\ Email: imprensauc@ci.uc.pt \\ URL: http://www.uc.pt/imprensa_uc}

\section{CONCEPÇÃO GRÁFICA}

António Barros

Pré-IMPRESSÃo

Tipografia Lousanense, Lda.

EXECUÇÃO GRÁFICA

Tipografia Lousanense, Lda.

ISBN

978-989-8074-74-4

DEPósito LEGAL

289002/09

OBRA PUBLICADA COM O APOIO DE:

Centro de Estudos Clássicos e Humanísticos

Faculdade de Letras da Universidade de Coimbra

FCT Fundação para a Ciência e a Tecnologia

MINISTÉRIO DA CIÊNCIA, TECNOLOGIA E ENSINO SUPERIOR Portugal 
Maria de Fátima Silva

Coordenação
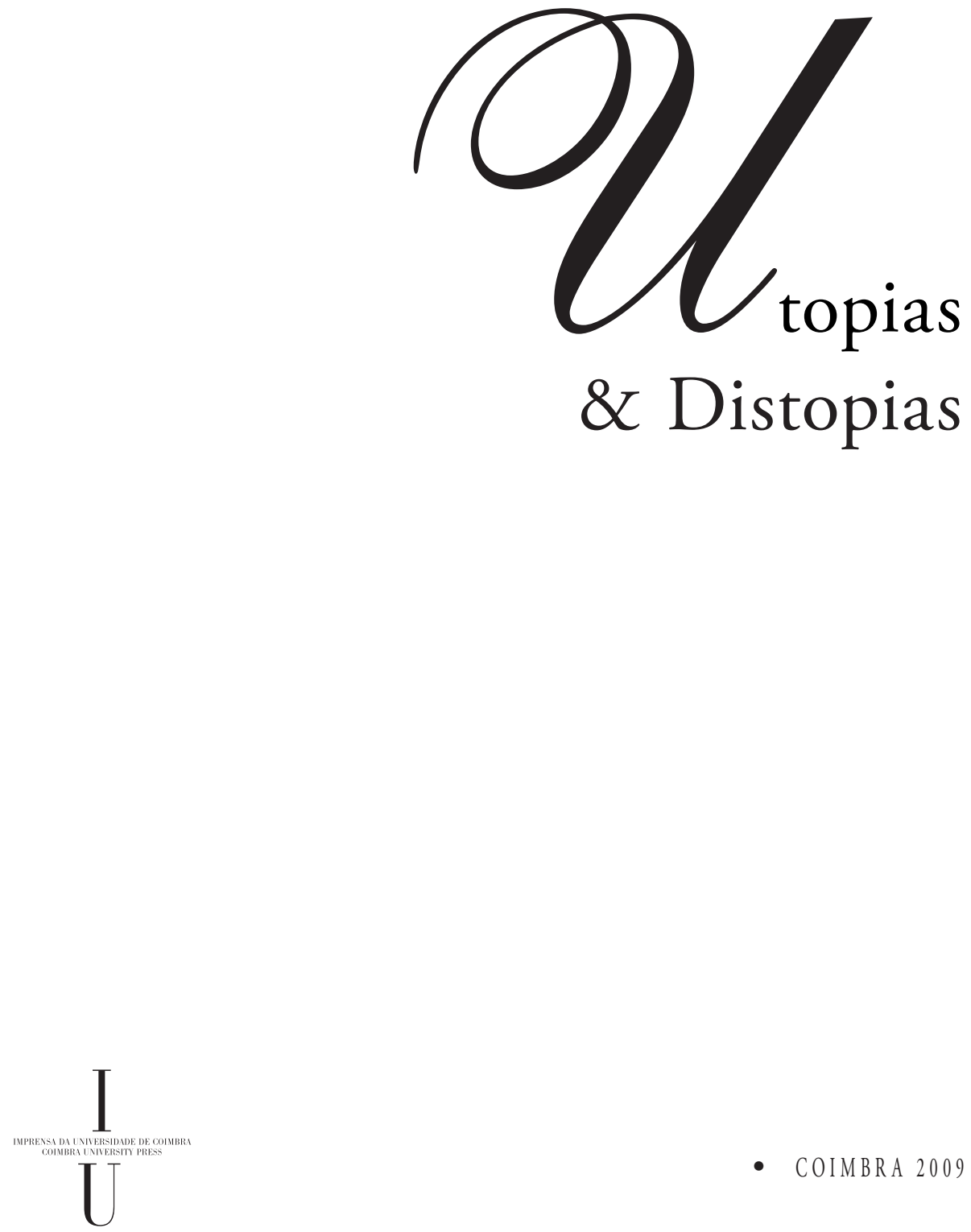

- colmbra 2009 



\section{Susana Hora Marques}

\section{UTOPIAS DISTÓPICAS NA TRAGÉDIA}

O sonho, espaço por excelência da utopia, distingue-se contudo na produção trágica de Ésquilo, Sófocles e Eurípides como um mundo distópico, do qual via de regra está ausente qualquer sugestão de felicidade ou de concretização de aspiraçóes: para boa parte dos receptores, sonhar equivale a debater-se com pesadelos. Uma tal correspondência relaciona-se decerto com o facto de as visóes oníricas confrontarem os mortais com um destino por hábito pressago e inevitável, desencadeador usual de angústia e sofrimento, que favorece a concretização do que Aristóteles define como um enredo trágico bem elaborado: a mudança < da acção> verifica-se «não da infelicidade para a ventura, mas, pelo contrário, da prosperidade para a desgraça, (...) por efeito (...) de um erro grave ${ }^{1}$ ». O imaginário dá assim a conhecer às personagens a realidade trágica em que acabam por se ver envolvidas, através de uma linguagem enigmática, desafiadora da interpretação humana. Ilusão e evidências entrecruzam-se, numa combinação que converte utopia em dor, em desgraça, em distopia, pela revelaçáo de circunstâncias que abrem caminho ao conhecimento verdadeiro sobre a realidade. Nesta perspectiva, é bem expressivo o desabafo de Etéocles nos Sete contra Tebas quando, por adesão voluntária à determinação do destino, decide defrontar o próprio irmão, Polinices, na defesa da sétima porta do reino tebano que então governava (cf. A., Th. 672-675): "como eram verdadeiras as visôes dos meus sonhos" (710-711), exclama. A percepção de um futuro trágico iminente e efectivo, antecipado já pela leitura simbólica do escudo exibido por Polinices (cf. 642 sqq.), e reiteradamente lembrado na peça pela revelação do sentido das maldiçôes de Édipo sobre o fim dos seus descendentes (e.g., 695-697), incita Etéocles a atribuir um significado definido, de infortúnio, às suas visōes sonhadas, nas quais via os bens paternos divididos. Assumindo a predisposição do destino (cf. 672 sqq.), o herói luta contra o irmão, num combate onde ambos encontram a morte em simultâneo, como é sabido. O herdeiro do decifrador de enigmas mostra-se deste modo um homem lúcido na interpretação que faz do seu destino, antevisto afinal através do sonho. A imagem da divisão de bens, recorrente nos Sete contra Tebas, simbolizava que os dois irmáos partilhariam o momento da morte e os palmos de terra que os sepultariam.

\footnotetext{
1 Aristóteles, Poética, 1453a. As traduçôes da Poética são citadas de A. M. Valente (Lisboa, 2004).
} 
$\mathrm{Na}$ produção esquiliana, a combinação entre o motivo onírico e a premonição de desgraça é particularmente expressiva nas experiências de Atossa e de Clitemnestra (cf. respectivamente Pers. 176-214 e Ch. 22 sqq., 526 sqq.): incluídas num conjunto de sinais reveladores da intervenção da justiça divina no destino humano, contribuem em qualquer um dos casos para reflectir o próprio sentido global da tragédia em que se inserem ${ }^{2}$. As situaçóes em que as rainhas sonham são paralelas: ambas são garantes de uma soberania que deveriam preservar durante a ausência dos monarcas entáo no trono ${ }^{3}$, além de que são ainda as mães dos herdeiros régios, ansiosas quanto ao regresso dos filhos. Atossa, todavia, deseja que Xerxes volte para continuar a governar o império persa, ao passo que Clitemnestra, assassina de Agamémnon e usurpadora do seu poder, receia naturalmente a vinda de Orestes, filho e sucessor legítimo do Atrida.

Nos Persas, Atossa, angustiada, conta com detalhe aos notáveis anciãos do seu país o sonho perturbador da noite precedente, numa narrativa em que se combinam, de forma sintomática, elementos visuais e cinéticos (cf. 176 sqq.). Duas mulheres de estatura elevada, muito belas e bem vestidas, irmãs do mesmo sangue que haviam optado por pátrias diferentes - a Hélade e a terra bárbara -, discutiam entre si. O jovem Xerxes procurava acalmá-las, “...ao mesmo tempo que as jungia ao seu carro e lhes punha os arreios ao pescoço. E, enquanto uma se envaidecia deste aparato, oferecendo ao freio uma boca dócil, a outra empinava-se, fazia em pedaços as rédeas, arrastava à força o carro e partia o jugo ao meio" ${ }^{4}$, prenunciando com o seu acto a derrota de Xerxes e dos seus homens diante dos Helenos: a habitual supremacia persa não seria capaz de se estender à Grécia. A realçar tal presságio, a visão transtornante da queda do soberano no carro e a percepção que ele próprio tem de Dario junto de si, compadecido. A imagem do pai, apresentado na peça como um rei sábio e prudente, instiga Xerxes a rasgar as vestes, em sinal da culpa que sente pelo falhanço da empresa (cf. 197 sqq.). As roupas das duas personagens evidenciariam então, por certo, as diferenças claras entre pai e filho: o velho rei distinguir-se-ia pelo esplendor particularmente adequado a um monarca persa, familiarizado com a riqueza, com a sumptuosidade, enquanto Xerxes surge aos olhos de Atossa com as vestes esfarrapadas, no sonho como depois, na realidade 5 . Deste modo, a glória e o sucesso passados de Dario parecem contrapor-se a um presente desastroso, embora não fatal

\footnotetext{
2 A este propósito, cf. R. Aélion, 'Songes et prophéties d'Eschyle: une forme de myse en abyme', Lalies. Actes des séssions de linguistique et de littérature III (Paris, 1984), pp. 133-146.

3 Como é sabido, após a morte de Dario, Xerxes subira ao trono da Pérsia e, procurando continuar a política de conquistas do pai <e dos soberanos Persas em geral>, partira numa expedição militar contra a Hélade: Atossa encontrava-se entấo sem o filho, numa corte sem monarca. Clitemnestra, por seu turno, vira Agamémnon ausentar-se do palácio durante longos anos para comandar a guerra contra Tróia e, no regresso do marido, assassinara-o, pactuando com Egisto. Orestes, o herdeiro legítimo do trono de Agamémnon, fora entretanto afastado da casa real. Atossa e Clitemnestra encaravam a autoridade régia com uma expectativa inversa: se a rainha persa sentia a necessidade de devolver o trono ao seu rei, a soberana de Argos, ao contrário, competia com aquela autoridade.

${ }^{4}$ Ésquilo, Os Persas. As traduçôes dos Persas são citadas de M. O. Pulquério (Lisboa, 1998).

5 Segundo W. G. Thalmann, 'Xerxes' rags: some problems in Aeschylus' Persians', AJPh 101.3 (1980), p. 263, é opinião geral hoje em dia que Xerxes se apresenta em cena com as vestes esfarrapadas. Sobre a polémica relacionada com esta questão, cf. O. Taplin, The stagecraft of Aeschylus (Oxford, 1977), pp. 121-123.
} 
para Xerxes, que acaba por regressar para junto de Atossa, carregando todavia consigo a humilhação de uma estrondosa derrota. O sonho, aliado na peça a outros sinais, constitui o reflexo efectivo de uma triste realidade, como de resto a própria receptora reconhece, ao ouvir as más notícias trazidas por um mensageiro, cujo discurso antecede ainda a chegada de Xerxes (cf. 517 sqq.): "Ai de mim, infeliz, que vejo o meu exército destruído! Ó nítida visão dos meus sonhos nocturnos, com que verdade me mostraste estes males!". Como Etéocles nos Sete contra Tebas, também aqui a rainha bárbara é capaz de ver as revelaçóes do imaginário convertidas em evidências geradoras de infortúnio, numa identificação clara e indesejável entre ilusão e realidade inevitável.

Nas Coéforas, o sonho constitui um sinal anunciador de um destino fatal para a própria receptora, Clitemnestra, depois de ela ter feito de Egisto seu amante e de, juntamente com ele, ter usurpado o trono a Agamémnon, seu marido, cujo assassínio a rainha foi também capaz de premeditar e realizar. A visão sonhada surge então como um meio de revelar a sorte funesta da filha de Tíndaro, decorrente de acçóes merecedoras de castigo, inscrevendo desde logo o mundo fictício num horizonte trágico. O próprio momento privilegiado para a ocorrência do sonho, a noite, reveste-se de particular significado, aqui como na produçáo trágica em geral, ao permitir acentuar a tonalidade obscura por norma associada àquele tipo de experiência, devida ao habitual carácter pressago da mesma. Em contraste com o silêncio e a tranquilidade nocturnos, o sonho destaca-se como um meio de perturbação dos receptores, gerador de terror, manifestado nas Coéforas ora através de gritos (cf. 34-35), ora de invocações e preces desesperadas à Terra e aos deuses infernais (cf. 45). Na verdade, as imagens vistas por Clitemnestra situam-na num universo distópico, que procura em vão eliminar, pela oferta de libaçóes purificadoras de um sonho mau junto do túmulo de Agamémnon. Ficamos a saber pelo corifeu que, no decurso da noite, parecera à rainha ter dado à luz uma serpente; "como se de uma criança se tratasse", ela envolveraa em faixas e dera-lhe o seio. Porém, ao sorver o "doce leite", o ser monstruoso mordera o peito que o amamentava, provocando um coágulo. A maternidade contra-natura de Clitemnestra era assim ferida pela violência da sua própria cria. A imagem da mulher que amamenta o seu rebento sugere a ligação natural que existe, via de regra, entre mãe e filho, pese embora a natureza invulgar da cria então nascida. Ao abordar a relação entre a filha de Tíndaro e o descendente, o sonho, para lá de aludir ao falhanço da rainha como mãe, reflecte um conflito fundamental nas Coéforas, particularmente implicado com o assunto de que a peça se ocupa: a vingança da morte de Agamémnon. Ao tomar conhecimento do conteúdo do sonho materno, Orestes, regressado do exílio, identifica-se com a serpente capaz de dar cumprimento à visão, i. e., capaz de fazer coincidir ilusão com realidade. Qual intérprete de sonhos, o jovem entende a violência do animal como indicadora do fim merecido por Clitemnestra: “...depois de alimentar o monstro horrendo, (...) deverá sofrer morte violenta" ${ }^{6}$ (548-549), afirma, numa ilustração do princípio rathein ton erxanta (cf. A., Ag. 1564), presente na Oresteia e fundamental para a acção das Coéforas. Predisposto a realizar o matricídio, o jovem conclui então: "transformado em serpente, hei-de matá-la, como diz o seu

\footnotetext{
${ }^{6}$ Ésquilo, Oresteia. As traduçóes das Coéforas são citadas de M. O. Pulquério (Lisboa, 1998).
} 
sonho" (549-550). O filho da víbora, ele próprio uma víbora enquanto seu descendente, converte-se em agente de uma continuada violência familiar no palácio de Agamémnon. O sangue provocado pela serpente no sonho representa pois aquele que Orestes fará verter na realidade com a sua espada, ao assassinar a mãe. O contraste cromático entre a brancura do leite materno e o vermelho que o tinge realça a ideia de que o jovem é, ao mesmo tempo, o filho e o assassino de Clitemnestra, para lá de patentear aos olhos das restantes personagens e do público, com um realismo que estimula à recriaçáo, imagens apenas vistas pela rainha. A leitura do sonho como uma profecia por aquele que se mostra disposto a ser o instrumento dos desígnios divinos determina-o finalmente a pôr em marcha os planos necessários para levar a cabo a punição da filha de Tíndaro, concretizando o pesadelo por ela sonhado.

A rainha, confrontada com Orestes e com a iminência da consumação do matricídio, descodifica perante o filho o verdadeiro significado do sonho (cf. 928-929). Com efeito, num momento intenso em emoçóes, a sonhadora, prestes a tornar-se uma vítima, confirma a interpretação dada às imagens por aquele que em breve se revelará seu assassino, vendo nele a representação efectiva da serpente que gerara e criara. A decifração consonante da experiência por parte da receptora e do matricida, para lá de pôr em evidência a relação mãe/ filho, favorece ainda a noção de que o termo da vida da criminosa às mâos do seu descendente é inevitável: o sonho implica uma realizaçáo fatal. As palavras e os gestos de Clitemnestra, na esperança ainda de deter o acto vingador de Orestes, revelam-se vãos (cf. 896-898): o cumprimento, na realidade, daquilo que começou por ser visto como uma terrível ilusão, intensifica as emoçôes das personagens e dos espectadores, permitindo que "a tragédia (...), por meio da compaixão e do temor, provoque a purificação de tais paixóes"7.

As visôes oníricas destacam-se pois na produção trágica como um meio de antecipação de uma realidade funesta. O imaginário individual traduz e /ou provoca receios, mais tarde convertidos em desafortunadas e indesejáveis certezas para os sonhadores: aos cenários idílicos, paradisíacos, utópicos, não raro associados ao motivo do sonho, sobrepóem-se os quadros infernais, distópicos da tragédia ática em geral, na época clássica.

A relação entre sonho e distopia na produção trágica não se confina à literatura grega: prossegue na literatura latina, desde logo, e encontramo-la também nos dramaturgos portugueses, numa pervivência que testemunha o interesse de ambos os motivos da tradição dramática helénica mesmo no mundo contemporâneo. Entre os latinos, destacamos o teatro de Séneca e pseudo-senequiano, bem recheado de experiências sonhadas, nomeadamente nas Troianas, onde Andrómaca se mostra atemorizada por um sonho pressago relativo ao destino do pequeno Astíanax (acto terceiro), ou na Octávia, que póe em cena Popeia a descrever à Ama a visão em sonhos do espectro de Agripina, prenúncio de uma revolução do povo, que estava iminente (acto terceiro).

Autores renascentistas portugueses como António Ferreira e Diogo de Teive retomam o motivo do sonho prenunciador de infortúnio, respectivamente na tragédia Castro e na Ioannes Princeps; as receptoras oníricas, D. Inês de Castro e a rainha D.

7 Arist., Po. 1449 b. 
Catarina, esposa de D. João III, exibem a habitual angústia resultante de sonhos aterrorizadores, sinais de um destino funesto, que adensam o clima trágico. Através de uma linguagem simbólica, D. Inês, na Castro, antevê a própria morte às mãos de «uns bravos lobos (...) que os peitos <lhe> rasgavam» (acto terceiro, 57-59); a D. Catarina, na Ioannes Princeps, o sonho pressagia-lhe a morte do único filho que ainda lhe restava, o príncipe D. João, embora deixe no ar uma ténue esperança infundida pela «pequenina centelha que sai do último olho <do monstro>, (...) já (...) privado da luz antiga ${ }^{8}$ (o futuro rei D. Sebastiáo).

Almeida Garrett, no século XIX, no Frei Luis de Sousa, imagina a jovem Maria a sonhar com um «anjo que descia com uma espada de chamas na mão» e a atravessava entre si e a mãe, imagens anunciadoras da morte de Maria (acto terceiro, cena onze).

Os dramaturgos portugueses contemporâneos fazem igualmente jus à tradicional relação entre sonho e tragédia, nomeadamente Bernardo Santareno, no Judeu, ao criar o sonho premonitório de Lourença, mãe do judeu, pelo recurso a efeitos cénicos distantes da tragédia helénica: na verdade, em vez da descrição que o receptor costuma fazer da sua experiência, o sonho profético de Lourença é dado a conhecer através da projecção num ecrã de fragmentos de documentários dos campos de concentração nazis para judeus, durante a Segunda Guerra Mundial, prenúncio da condenação à morte de António José da Silva pelo Tribunal da Inquisição (acto terceiro). Na peça António Marinheiro, Santareno recria no cenário da Alfama lisboeta o mito de Édipo, acentuando as semelhanças com a tragédia sofocliana Rei Édipo; ao contrário do poeta ateniense, porém, Santareno insere o motivo do sonho, enquanto sinal que permite à protagonista, Amália, antever desgraças futuras, decorrentes do seu casamento com o próprio filho, António. A primeira obra dramática de Paulo José Miranda, O corpo de Helena, realça também, por seu turno, a natureza distópica do sonho: Menelau, o protagonista desta interessante versão da história dos Atridas, sonha com o triste destino reservado a Ifigénia, sacrificada pelo próprio pai.

Pese embora o tratamento paradigmático do sonho trágico como pesadelo, quero hoje continuar a acreditar, como Sebastiâo da Gama, que "pelo sonho é que vamos", já que, como afirma de modo entusiástico Sophia de Mello Breyner Andresen no poema de abertura do volume intitulado Poesia, escrito na sua juventude,

«Apesar das ruínas e da morte, onde sempre acabou cada ilusão, a força dos meus sonhos é tão forte, que de tudo renasce a exaltação e nunca as minhas mãos ficam vazias».

8 Trad. de N. C. Soares, Diogo de Teive, Tragédia do Príncipe João (Lisboa², 1999), 151, vv. 84-86. 


\section{Série}

\section{Documentos}

Imprensa da Universidade de Coimbra

Coimbra University Press

2009

- $\mathrm{U}$

C • 